Journal of Animal and Veterinary Advances 11 (5): 655-661, 2012

ISSN: $1680-5593$

(C) Medwell Journals, 2012

\title{
Incidence of Enterotoxin-Producing MRSA in Bovine Mastitis Cases, Bulk Milk Tanks and Processing Plants in Thailand
}

\author{
${ }^{1}$ Manakant Intrakamhaeng, ${ }^{3}$ Tanaya Komutarin, ${ }^{2}$ Komkrich Pimpukdee and ${ }^{4}$ Worapol Aengwanich \\ ${ }^{1}$ Department of Biology, Faculty of Science, Mahasarakham University, 44150 Mahasarakham, Thailand \\ ${ }^{2}$ Department of Veterinary Public Health, Faculty of Veterinary Medicine, \\ Khon Kaen University, 40002 Khon Kaen, Thailand \\ ${ }^{3}$ Faculty of Medicine, ${ }^{4}$ Faculty of Veterinary and Animal Sciences, Mahasarakham University, \\ 44000 Mahasarakham, Thailand
}

\begin{abstract}
Methicillin Resistant S. aureus (MRSA) are virulent strains of $S$. aureus which have become resistant to most antibiotics. The emergence of MRSA is a serious public health concern worldwide. The present study sought to determine the distribution of enterotoxin-producing MRSA in Thailand using multiplex PCR. A total of 375 S. aureus isolates obtained from 598 mastitis cases, 376 bulk tank milk samples and 46 pasteurized milk samples were investigated for phenotypic methicillin resistance. Of these 375 isolates, 74 were found to be methicillin resistant. Variation in the SE encoding genes was detected. A total of 61 isolates harbored at least one classical $S E$ gene, 30 isolates possessed only one type of enterotoxin gene and the remaining 31 were found to be positive for more than one toxin gene. The genes most frequently detected were seb and sed. Isolates obtained from mastitis cases had the highest incidence of enterotoxin genes followed by bulk milk isolates. On comparing the data relative to the different dairy locations, the isolates from Khon Kaen province harbored most detected enterotoxin genes. This was the only location where MRSA isolates from both mastitis milk and bulk milk were found harboring enterotoxin genes. Among the $5 \mathrm{~S}$. aureus strains isolated from pasteurized milk only one isolate was MRSA. The strain which was isolated in Mahasarakham was positive for the sed gene. The current study has detected enterotoxigenic MRSA in mastitis milk, bulk milk and also pasteurized milk from Thailand. Further detailed analysis of functional genomics is now warranted to gain a better understanding of enterotoxin activity and virulence.
\end{abstract}

Key words: MRSA, enterotoxin, milk, isolates, harbored, virulence

\section{INTRODUCTION}

Staphylococcus aureus is one of the most pathogenic bacteria causing contagious bovine mastitis. Although, a variety of antibiotics can be used against this organism, S. aureus mastitis has been found to respond poorly to antibiotic treatment (Barkema et al., 2006). Methicillin Resistant $S$. aureus (MRSA) is one of a number of virulent $S$. aureus strains which have become resistant to most antibiotics (Van Loo et al., 2007). The spread of $S$. aureus especially, MRSA has been remarkable and its control has become a major challenge in Thailand.

Some strains of $S$. aureus can express a large number of virulence factors including Staphylococcal Enterotoxins (SEs). SEs are recognized as the main agents of Staphylococcal Food Poisoning (SFP) in humans (Dego et al., 2002; Peacock et al., 2002).
SEs are remarkably heat resistant and it is possible for them to retain biological activity after the thermal process of pasteurization (Rall et al., 2008; Normanno et al., 2007). The classical SEs have been characterized into five serological types (SEA-SEE) on the basis of their antigenicity (Bergdoll et al., 1974). These toxins are responsible for food poisoning outbreaks and are important in terms of food safety.

Many studies indicate that enterotoxin production can be observed in bovine milk and a great diversity of SE encoding genes have been found among $S$. aureus isolates (Akineden et al., 2001; Katsuda et al., 2005; Cremonesia et al., 2005; Moon et al., 2007; Jorgensen et al., 2005).

Little data is available on the epidemiology of MRSA strains from animal origin in Thailand. The aim of the present investigation was to study distribution of MRSA

Corresponding Author: Worapol Aengwanich, Faculty of Veterinary and Animal Sciences, Mahasarakham University, 44000 Mahasarakham, Thailand 
harboring the major SE genes using multiplex PCR. Such information can give an indication of the virulence of MRSA present in different areas on the basis of comparison between different sources of milk. To ensure safety of milk consumers, surveilance of the entire production chain for pathogens is required. Therefore, this survey compared different sources of milk including mastitis cases, bulk milk tanks and pasteurized milkprocessing plants.

\section{MATERIALS AND METHODS}

Source of $S$. aureus isolates: The eight milk-producing provinces in Thailand, Khon Kaen, Mahasarakham, Udon Thani, Loei, Sakon Nakhon, Nakhon Ratchasima, Lop Buri and Sara Buri (Fig. 1) were surveyed to investigate the emergence of MRSA. For mastitis milk sample collection, the California Mastitis Test (CMT) was applied in 598 farms to diagnose bovine mastitis cows with somatic cell counts greater than $5 \times 10^{5}$ cells $\mathrm{mL}^{-1}$. One sample from each farm was aseptically collected $(\sim 10 \mathrm{~mL})$. Bulk tank milk samples from 376 bulk lots of milk were collected from 28 milk collection centers. For pasteurized milk samples, researchers collected 46 samples from 3 districts where pasteurized milk plants were located. An aliquot of each sample was simultaneously spread onto a plate containing Baird-Parker's medium (Oxoid Ltd., Thailand) and incubated under aerobic conditions at $37^{\circ} \mathrm{C}$ for $24 \mathrm{~h}$. All grey-black shiny convex 1-1.5 mm diameter colonies obtained were presumed to be $S$. aureus. Identification of these presumptive $S$. aureus colonies was based on standard biological tests including gram staining, colony morphology, catalase test and coagulase test using human plasma. All S. aureus isolates were examined for methicillin resistance.

Detection of MRSA: MRSA isolates were detected by antibiotic disc diffusion using $1 \mu \mathrm{g}$ oxacillin and $30 \mu \mathrm{g}$ cefoxitin (Oxoid Ltd., Thailand). The usefulness of this method for accurately detecting MRSA has recently been described by many researchers (Anand et al., 2009; Zeeshan et al., 2007; Stepanovic et al., 2006; Velasco et al., 2005; Brown et al., 2005). Mueller-Hinton agar was used as recommended by the Clinical and Laboratory Standards Institute (CLSI). Bacterial suspensions equal to a $0.5 \mathrm{McF}$ arland standard for $1 \times 10^{8} \mathrm{CFU} \mathrm{mL}^{-1}$ were prepared in $0.9 \%$ saline. In order to monitor the susceptibility test, methicillin sensitive S. aureus ATCC 25923 and methicillin resistant S. aureus DMST 20625 were used as negative and positive controls, respectively. Both reference strains were from the Department of Medical Sciences, Ministry of Public Health, Thailand. Zones of inhibition were measured after $24 \mathrm{~h}$ of incubation at $37^{\circ} \mathrm{C}$ and results were interpreted according to CLSI recommendations. Each isolate was tested in duplicated and mean zone of inhibition diameters were determined. Isolates with both oxacillin resistances (inhibition zone diameter $\leq 10 \mathrm{~mm}$ ) and cefoxitin resistances (inhibition zone diameter $\leq 21 \mathrm{~mm}$ ) were identified as MRSA and selected for detection of SE genes.

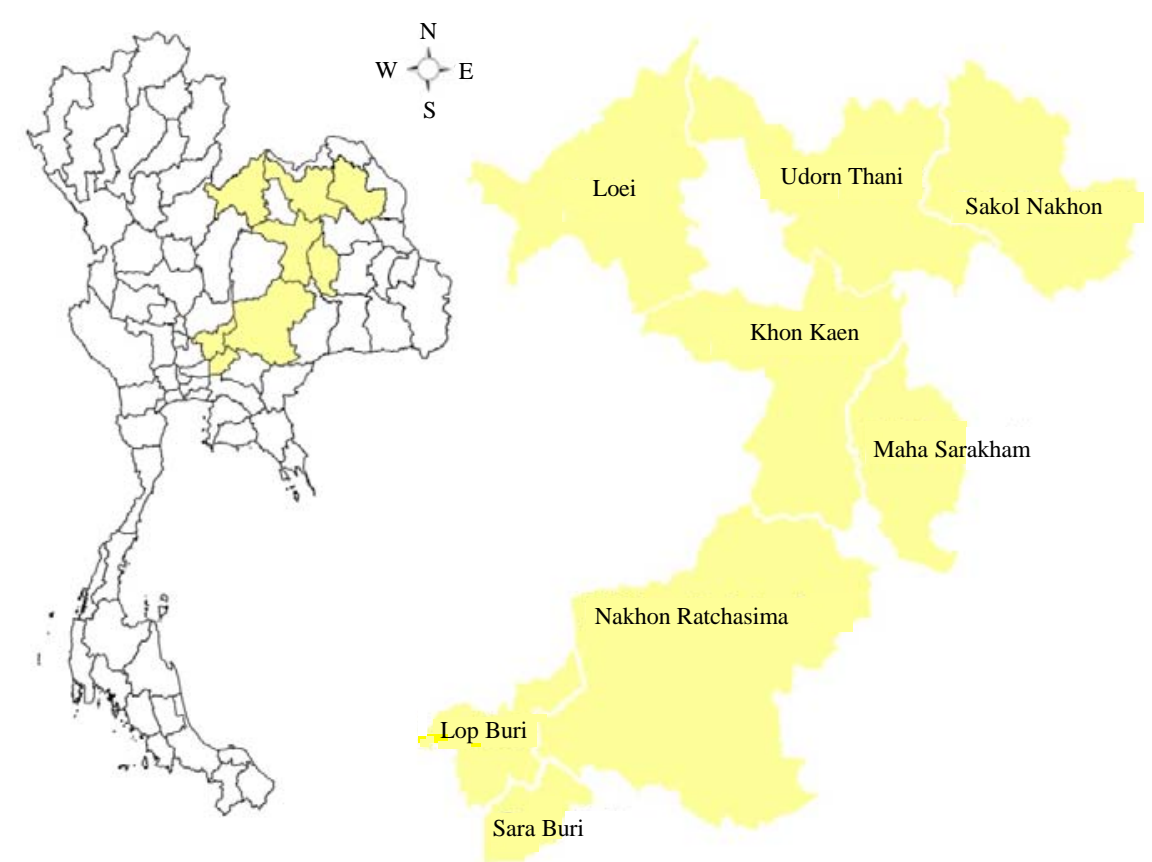

Fig. 1: Geographical location of study area 
Table 1: Oligonucleotide primers for amplification of genes encoding staphylococcal enterotoxins

\begin{tabular}{|c|c|c|c|c|}
\hline Genes & Sequence $\left(5^{\prime}-3^{\prime}\right)$ & $\begin{array}{c}\text { Base } \\
\text { pair }\end{array}$ & $\begin{array}{l}\text { Annealing } \\
\text { Temp }\left({ }^{\circ} \mathrm{C}\right)\end{array}$ & References \\
\hline sea & $\begin{array}{l}\text { ttggaaacggttaaaacgaa } \\
\text { gaaccttcccatcaaaaaca }\end{array}$ & 120 & 50 & Johnsonetal. (1991) \\
\hline$s e b$ & $\begin{array}{l}\text { tcgcatcaaactgacaaacg } \\
\text { gcaggtactctataagtgcc }\end{array}$ & 478 & 50 & Johnsonetal. (1991) \\
\hline $\mathrm{sec}$ & $\begin{array}{l}\text { gacataaaagctaggaattt } \\
\text { aaatcggattaacattatcc }\end{array}$ & 257 & 50 & Johnsonetal. (1991) \\
\hline sed & $\begin{array}{l}\text { ctagtttggtaatatctcct } \\
\text { taatgctatatcttataggg }\end{array}$ & 317 & 50 & Johnsonetal. (1991) \\
\hline
\end{tabular}

Genomic DNA extraction: MRSA isolates were grown overnight in Brain-Heart Infusion broth (BHI) (Oxoid Ltd., Thailand) at $37^{\circ} \mathrm{C}$. DNA extraction was carried out using a Genomic DNA Extraction Kit (RBC bioscience, Taiwan). Purity and concentration of the DNA were measured using a NanoDrop 1000 spectrophotometer (Thermo Fisher Scientific, USA). About 100 ng of the genomic DNA was used for mPCR analysis.

mPCR testing for genes encoding staphylococcal enterotoxins: Detection of enterotoxin genes by multiplex PCR was performed. After DNA isolation, amplification of selected genes (enterotoxin genes sea, seb, sec and sed) was achieved using 4 primer sets in a $25 \mu \mathrm{L}$ reaction mixture containing $1 \mu \mathrm{L}$ DNA sample, $12.5 \mu \mathrm{L}$ Bluemix DNA Polymerase Mastermix ${ }^{\circledR}$ (RBC bioscience, Taiwan) and molecular-grade water. All DNA primers (Table 1) were synthesized by Biodesign (Thailand). DNA amplification was performed using the following conditions: initial denaturation for $5 \mathrm{~min}$ at $94^{\circ} \mathrm{C}$ followed by 30 cycles of denaturation $\left(94^{\circ} \mathrm{C}\right.$ for $2 \mathrm{~min}$ ), annealing and extension $\left(72^{\circ} \mathrm{C}\right.$ for $\left.1 \mathrm{~min}\right)$. The oligonucleotide primers and annealing temperatures used were those recommended by Johnson and are shown in Table 1. A final extension step $\left(72^{\circ} \mathrm{C}\right.$ for $\left.5 \mathrm{~min}\right)$ was performed after completion of the cycles. $S$. aureus strains harboring known enterotoxins were used as positive controls. These included S. aureus ATCC 13565 (sea), S. aureus ATCC 14458 (seb), S. aureus ATCC 19095 (sec) and S. aureus ATCC 23235 (sed).

After amplification, PCR products were analysed using $1.5 \%$ agarose gel with $0.125 \mathrm{mg} \mathrm{L}^{-1}$ ethidium bromide. A 100 bp ladder (Invitrogen) was run together with PCR products as a molecular weight marker. PCR banding sizes generated with each primer were measured by GelixOne G230 Software (Biostep, Denmark). Only clear, unambiguous and reproducible bands were recorded.

\section{RESULTS AND DISCUSSION}

Incidence of MRSA: Out of 1,020 milk samples, comprising milk from 598 mastitis cows, 376 bulk milk
Table 2: Zones of inhibition ( $\mathrm{mm}$ ) produced by oxacillin and cefoxitin against MRSA isolates from different sources

\begin{tabular}{lcccr}
\hline Antibiotics & $\begin{array}{c}\text { Mastitis cows } \\
(\mathrm{n}=51)\end{array}$ & $\begin{array}{c}\text { Bulk milk } \\
\text { tanks }(\mathrm{n}=22)\end{array}$ & $\begin{array}{c}\text { Pasteurized } \\
\text { milk }(\mathrm{n}=1)\end{array}$ & $\begin{array}{c}\text { Total } \\
(\mathrm{n}=74)\end{array}$ \\
\hline Oxacillin & $6.1 \pm 0.4$ & $6.0 \pm 0.0$ & $6.0 \pm 0.0$ & $6.1 \pm 0.4$ \\
Cefoxitin & $11.0 \pm 5.1$ & $13.5 \pm 3.5$ & $21.0 \pm 0.0$ & $11.9 \pm 4.9$ \\
\hline
\end{tabular}

tanks and 46 samples of pasteurized milk, $375(36.8 \%)$ were found to contain $S$. aureus. Mastitis milk showed the highest incidence of S. aureus contamination (38.3\%, 229 of 598 samples) followed by bulk milk tanks ( $37.5 \%, 141$ of 376 samples) and pasteurized milk $(10.9 \%, 5$ of 46 samples). All $375 \mathrm{~S}$. aureus isolates were examined for methicillin resistance using $1 \mu \mathrm{g}$ oxacillin and $30 \mu \mathrm{g}$ cefoxitin discs. The zones of inhibition generated are shown in Table 2. Seventy four of the isolates $(19.7 \%$ of $375 \mathrm{~S}$. aureus isolates) were identified as MRSA using CLSI guidelines (Clinical and Laboratory Standard Institute, 2009). MRSA isolates exhibited inhibition zone diameters of $6.1 \pm 0.4 \mathrm{~mm}$ around oxacillin discs. In diffusion tests with $30 \mu \mathrm{g}$ cefoxitin discs, MRSA isolates exhibited inhibition zone diameters of $11.9 \pm 4.9 \mathrm{~mm}$. MRSA isolates from mastitis milk expressed resistance to cefoxitin with small zone size $(11.0 \pm 5.1 \mathrm{~mm})$ while the cefoxitin zone diameters were higher for 22 isolates from bulk tanks and one isolate from pasteurized milk (13.5 \pm 3.5 and $21.0 \pm 0.0 \mathrm{~mm}$, respectively). According to Table 3 , the incidence of MRSA positive isolates was high in mastitis milk $(22.3 \%, 51$ of 229 isolates $)$. The proportion of $S$. aureus isolates obtained from bulk milk and pasteurized milk identified as MRSA was $15.6 \%$ (22 of 141 isolates) and $20.0 \%$ ( 1 of 5 isolates ), respectively.

The incidence of methicillin resistant isolates varied according to the dairy locations (Table 3). No MRSA isolates were present in Loei, Sakon Nakhon or Sara Buri. Interestingly, most of the MRSA (30 of 74 isolates) were found in mastitis milk from just 2 locations: 15 isolates obtained from the Phangthui district of Khon Kaen and 15 isolates obtained from the Srithaat district of Udon Thani. This represents a very high level of MRSA at both locations (42.9 and 41.7\%, respectively) (Table 3 ).

Distribution of SE: According to the results of multiplex PCR analysis of all isolates (Table 3 ) a total of 61 isolates $(82.4 \%)$ harbored at least one classical $S E$ gene whereas 13 isolates $(17.6 \%)$ were negative. Thirty isolates possessed only one type of enterotoxin gene and the remaining 31 were found to be positive for more than one toxin gene.

With regard to the $74 \mathrm{MRSA}$ isolates examined, the genes most commonly detected were seb (12 isolates, $16.2 \%$ ) and sed (12 isolates, $16.2 \%$ ). The number of sea and sec positive isolates was 6.8 and $1.4 \%$, respectively. The presence of enterotoxin genes was most commonly 
Table 3: Incidence of MRSA isolates harboring classical SE encoding genes

\begin{tabular}{|c|c|c|c|c|c|c|c|c|c|c|c|c|c|c|c|c|c|}
\hline \multicolumn{2}{|c|}{$\begin{array}{l}\text { Locations } \\
\text { (Provinces and districts) }\end{array}$} & $\begin{array}{l}\text { Total } \\
\text { samples }\end{array}$ & $\begin{array}{l}\text { S. aureus } \\
\text { isolates } \\
\text { (n) }\end{array}$ & $\begin{array}{c}\text { MRSA } \\
\text { (n) }\end{array}$ & $\begin{array}{c}\text { SE } \\
\text { positive } \\
\text { (n) }\end{array}$ & sea & seb & $\mathrm{sec}$ & sed & $\begin{array}{l}\text { sea, } \\
\text { seb }\end{array}$ & $\begin{array}{l}\text { sea, } \\
\text { sed }\end{array}$ & $\begin{array}{l}s e b, \\
s e c\end{array}$ & $\begin{array}{l}\text { seb, } \\
\text { sed }\end{array}$ & $\begin{array}{l}\text { sec, } \\
\text { sed }\end{array}$ & $\begin{array}{l}\text { sea, } \\
\text { sec, } \\
\text { sed }\end{array}$ & $\begin{array}{l}\text { sea, } \\
\text { seb, } \\
\text { sed }\end{array}$ & $\begin{array}{l}\text { seb, } \\
\text { sec, } \\
\text { sed }\end{array}$ \\
\hline \multicolumn{18}{|c|}{ Mastitis cows (isolated from 598 milk samples) } \\
\hline \multirow[t]{3}{*}{ Khon Kaen } & Kra nuan & 78 & 22 & 1 & 1 & - & 1 & $\cdot$ & - & - & - & - & - & - & - & - & - \\
\hline & Nam phong & 71 & 35 & 4 & 4 & - & - & 1 & 3 & - & - & - & - & - & - & - & - \\
\hline & Phangthui & 48 & 35 & 15 & 13 & 2 & - & - & 1 & 3 & - & - & 4 & - & - & 3 & - \\
\hline \multirow[t]{3}{*}{ Lop Buri } & Nong ri & 36 & 7 & 3 & 3 & - & 1 & - & - & - & 1 & - & - & - & 1 & - & - \\
\hline & Suanmaduea & 24 & 16 & 7 & 6 & - & 2 & - & 1 & - & 1 & - & - & - & 2 & - & - \\
\hline & Sapkradan & 26 & 9 & 1 & 1 & - & - & - & - & - & - & - & 1 & - & - & - & - \\
\hline \multirow[t]{2}{*}{ Udon Thani } & Nongwuaso & 21 & 10 & 5 & 5 & - & 3 & - & - & - & - & 1 & 1 & - & - & - & - \\
\hline & Srithaat & 79 & 36 & 15 & 14 & - & 3 & - & 2 & 3 & - & - & 4 & - & - & - & 2 \\
\hline \multicolumn{2}{|c|}{ Other locations } & 215 & 59 & 0 & - & - & - & - & - & - & - & - & - & - & - & - & - \\
\hline \multicolumn{2}{|c|}{ Total } & 598 & 229 & 51 & 47 & 2 & 10 & 1 & 7 & 6 & 2 & 1 & 10 & - & 3 & 3 & 2 \\
\hline
\end{tabular}

Bulk milk tanks (isolated from 376 milk samples)

\begin{tabular}{|c|c|c|c|c|c|c|c|c|c|c|c|c|c|c|c|c|c|}
\hline \multirow[t]{4}{*}{ Khon Kaen } & Kra nuan & 17 & 10 & 1 & 1 & - & - & - & - & - & - & - & 1 & - & - & - & - \\
\hline & Nam phong & 15 & 12 & 3 & 3 & - & - & - & 2 & 1 & - & - & - & - & - & - & - \\
\hline & Phangthui & 22 & 13 & 2 & 1 & - & - & - & & 1 & - & - & - & - & - & - & - \\
\hline & $\begin{array}{l}\text { Muang Khon } \\
\text { Kaen }\end{array}$ & 17 & 10 & 4 & 3 & - & 2 & - & 1 & - & - & - & - & - & - & - & - \\
\hline \multirow[t]{2}{*}{ Maha Sarakham } & Kantharawicha & 48 & 16 & 2 & 1 & 1 & - & - & - & - & - & - & - & - & - & - & - \\
\hline & Khoh kho & 45 & 10 & 4 & 2 & 2 & - & - & - & - & - & - & - & - & - & - & - \\
\hline \multicolumn{18}{|l|}{ Nakhon } \\
\hline \multirow[t]{4}{*}{ Ratchasima } & Pak thong chai & 4 & 3 & 1 & 1 & - & - & - & 1 & - & - & - & - & - & - & - & - \\
\hline & Pak chong & 9 & 2 & 1 & 0 & - & - & - & - & - & - & - & - & - & - & - & - \\
\hline & Muak lek & 14 & 6 & 2 & 0 & - & - & - & - & - & - & - & - & - & - & - & - \\
\hline & Soeng sang & 6 & 1 & 1 & 1 & - & - & - & - & - & - & - & - & - & - & - & 1 \\
\hline \multicolumn{2}{|c|}{ Udon Thani Kutchap } & 9 & 5 & 1 & 0 & - & - & $\cdot$ & - & - & - & - & - & - & - & - & - \\
\hline \multicolumn{2}{|l|}{ Other locations } & 170 & 53 & 0 & & - & - & - & - & - & - & - & - & - & - & - & - \\
\hline \multicolumn{2}{|l|}{ Total } & 376 & 141 & 22 & 13 & 3 & 2 & 0 & 4 & 2 & - & - & 1 & - & - & - & 1 \\
\hline \multicolumn{18}{|c|}{ Pasteurized milk (isolatedfrom 46 milk samples) } \\
\hline Maha Sarakham & Khoh kho & 29 & 4 & 1 & 1 & - & - & - & 1 & - & - & - & - & - & - & - & - \\
\hline Other locations & & 17 & 1 & 0 & & - & - & - & - & - & - & - & - & - & - & - & - \\
\hline Total & & 46 & 5 & 1 & 1 & - & - & - & 1 & - & - & - & - & - & - & - & - \\
\hline $\begin{array}{l}\text { Total number of } \\
\text { examined MRSA }\end{array}$ & $\begin{array}{l}\text { samples } \\
\text { harboring }\end{array}$ & 1,020 & 375 & 74 & $\begin{array}{l}61 \\
(82.4 \%)\end{array}$ & $\begin{array}{l}5 \\
(6.8 \%)\end{array}$ & $\begin{array}{l}12 \\
(16.2 \%)\end{array}$ & $\begin{array}{l}1 \\
(1.4 \%)\end{array}$ & $\begin{array}{l}12 \\
(16.2 \%)\end{array}$ & $\begin{array}{l}8 \\
(10.8 \%)\end{array}$ & $\begin{array}{l}2 \\
(2.7 \%)\end{array}$ & $\begin{array}{l}1 \\
(1.4 \%)\end{array}$ & $\begin{array}{l}10 \\
(13.5 \%)\end{array}$ & $\begin{array}{l}1 \\
(1.4 \%)\end{array}$ & $\begin{array}{l}3 \\
(4.1 \%)\end{array}$ & $\begin{array}{l}3 \\
(4.1 \%)\end{array}$ & $\begin{array}{l}3 \\
(4.1 \%\end{array}$ \\
\hline
\end{tabular}
enterotoxin (\%)

detected in MRSA isolates obtained from mastitis milk. Most mastitis isolates $(92.2 \%, 47$ of 51 isolates) were positive for the presence of enterotoxin genes as were bulk milk isolates $(59.1 \%, 13$ of 22 isolates). Remarkably, one of the isolates from pasteurized milk was also found to be both methicillin resistant and enterotoxin gene positive.

Among the 47 mastitis isolates investigated, 2 isolates were found to be positive for the presence of sea genes, 10 isolates contained the gene for seb, 1 isolate contained the gene encoding sec, 7 isolates contained the gene for sed and the remaining isolates harbored combinations of these. The detection of multiple types of toxin gene was more common among MRSA isolates from mastitis milk than those from bulk milk tanks or pasteurized milk. The results show that seb and sed are the predominant genes.

On comparing the data relative to the different dairy locations, the isolates taken from Khon Kaen harbored most detected enterotoxin genes. Other locations where enterotoxin genes were frequently detected were the provinces of Udon Thani and Lop Buri. Khon Kaen was the only location where MRSA isolates from both mastitis milk and bulk milk were found haboring enterotoxin genes. Among the $5 S$. aureus strains isolated from pasteurized milk only one was methicillin resistant and enterotoxin positive. This strain was isolated in Mahasarakham and was positive for the sed gene.

Throughout the world, $S$. aureus is a frequent cause of bovine mastitis. According to the investigation, S. aureus infection or contamination was present in $38.3 \%$ of herds, $37.5 \%$ of bulk lots of milk and $10.9 \%$ of pasteurized milk samples. This serves as a warning that $S$. aureus is widespread in this region and may pose a health risk to consumers. Inadequate hygiene on farms and during milk transportation may have contributed to the spread of $S$. aureus in these areas. The study sought to assess the virulence of these isolates using tools for MRSA identification and enterotoxin gene detection. A total of 74 isolates were identified as methicillin resistant based on the size of zones of inhibition produced by oxacillin and cefoxitin. This represents the first report of MRSA strains being isolated from mastitis cases, bulk milk tanks and pasteurized milk in Thailand. Most MRSA 
isoaltes originated from mastitis cows. This finding correlates well with other studies. For example, Lee (2003) reported that 9 of $12 \mathrm{MRSA}$ isolates of milk origin were from cows with subclinical signs of matitis. Also, in a study by Moon et al. (2007) it was found that $2.8 \%$ of $S$. aureus from bovine mastitis cases were methicillin resistant. The occurrence and spread of MRSA in dairy farms is concerning because of possible transmission between cows and humans. According to the results of Lee (2003) and Juhasz-Kaszanyitsky et al. (2007), MRSA isolates of bovine and human origin are indistinguishable. Furthermore, MRSA of animal origin may contaminate foods and represent a source of MRSA infection or intoxication in humans. Therefore, the direction of genetic transfer warrants further investigation.

The high incidence of MRSA the study detected in specific locations is of interest. The two districts in question, Phangthui district of Khon Kaen and Srithaat district of Udon Thani are approximately $160 \mathrm{~km}$ apart and share a common route of milk transportation. The emergence of methicillin resistance in these regions may have been caused by excessive therapeutic use. S. aureus can adapt rapidly to the selective pressure of antibiotics and becomes methicillin resistant by the acquisition of the $m e c A$ gene. This gene encodes a Penicillin Binding Protein (PBP2a) with a low affinity for $\beta$-lactams (Ortega et al., 2010). The genetic relevance of these isolates should therefore be studied.

The incidence of MRSA isolates encoding classical $S E$ genes was high (82.4\%). The percentage of isolates that harbored enterotoxin genes increased $(92.2 \%)$ when only mastitis milk isolates were considered. In a previous study, Omoe et al. (2002) found that 15 S. aureus isolates ( $71.4 \%$ ) originating from cows with mastitis were positive for one or more enterotoxin genes. Sila et al. (2009) has indicated that the classical genes, sea, seb and sed are more frequently detected in MRSA than MSSA. The sec gene for enterotoxin $\mathrm{C}$ was also more frequent in MSSA. Absence of the see gene has been noted in several previous studies (Peacock et al., 2002; Becker et al., 2003; Boerema et al., 2006; Sila et al., 2009). Previous data indicate that the sea gene is most prevalent with SEA being involved in outbreaks of staphylococcal food poisoning worldwide (Gencay et al., 2010; Wang et al., 2009; Chiang et al., 2008).

The present study revealed that some isolates harbored the sea gene but that this was not predominant. In the study, seb and sed were the predominant enterotoxin genes in mastitis and bulk milk isolates. Boerema et al. (2006) and Peles et al. (2007) also reported that seb was the most commonly detected gene in strains isolated from bulk tank milk. Interestingly, the study also detected an MRSA isolate in pasteurized milk that harbored the sed gene. This discovery highlights a potential risk for consumers.

\section{CONCLUSION}

Results from this study indicate that MRSA has spread between different milk-producing locations in Thailand. This is of concern because it reduces the therapeutic options for mastitis treatment. Most of the isolates contaminating mastitis milk, bulk milk and pasteurized milk were also shown to be enterotoxigenic.

These findings suggest that further detailed analysis using functional genomics are warranted to gain a better understanding of enterotoxin activity and epidemiology.

\section{ACKNOWLEDGEMENTS}

This study was supported by a grant under the program Strategic Scholarships for Frontier Research Network for the Ph.D. Program Thai Doctoral Degree provided by the Commission on Higher Education, Ministry of Education, Thailand.

\section{REFERENCES}

Akineden, O., C. Annemuller, A.A. Hassan, C. Lammler, W. Wolter and M. Zschock, 2001. Toxin genes and other characteristics of Staphylococcus aureus isolates from milk of cows with mastitis. Clin. Diagn. Lab. Immunol., 8: 959-964.

Anand, K.B., P. Agrawal, S. Kumar and K. Kapila, 2009. Comparison of cefoxitin disc diffusion test, oxacillin screen agar and PCR for mecA gene for detection of MRSA. Indian J. Med. Microbiol., 27: 27-29.

Barkema, H.W., Y.H. Schukken and R.N. Zadoks, 2006. Invited review: The role of cow, pathogen and treatment regimen in the therapeutic success of bovine staphylococcus aureus mastitis. J. Dairy Sci., 89: 1877-1895.

Becker, K., A.W. Friedrich, G. Lubritz, M. Weilert, G. Peters and C. Eiff, 2003. Prevalence of genes encoding pyrogenic toxin superantigens and exfoliative toxins among strains of Staphylococcus aureus isolated from blood and nasal specimens. J. Clin. Microbiol., 41: 1434-1439.

Bergdoll, M.S., J.K. Czop and S.S. Gould, 1974. Enterotoxin synthesis by the staphylococci. Ann. N. Y. Acad. Sci., 236: 307-316. 
Boerema, J.A., R. Clemens and G. Brightwell, 2006. Evaluation of molecular methods to determine enterotoxigenic status and molecular genotype of bovine, ovine, human and food isolates of Staphylococcus aureus. Int. J. Food. Microbiol., 107: 192-201.

Brown, D.F., D.I. Edwards, P.M. Hawkey, D. Morrison and G.L. Ridgway et al., 2005. Guidelines for the laboratory diagnosis and susceptibility testing of methicillin-resistant Staphyloccocus aureus (MRSA). J. Antimicrob. Chemother., 56: 1000-1018.

Chiang, Y.C., W.W. Liao, C.M. Fan, W.Y. Pai, C.S. Chiou and H.Y. Tsen, 2008. PCR detection of Staphylococcal enterotoxins (SEs) N, O, P, Q, R, U and survey of SE types in Staphylococcus aureus isolates from food-poisoning cases in Taiwan. Int. J. Food Microbiol., 121: 66-73.

Clinical and Laboratory Standard Institute, 2009. Performance Standards for Antimicrobial Susceptibility Testing: 20th Informational Supplement. Clinical and Laboratory Standard Institute, Wayne, PA., USA.

Cremonesia, P., M. Luzzanaa, M. Brascab, S. Morandi and R. Lodi et al., 2005. Development of a multiplex PCR assay for the identification of Staphylococcus aureus enterotoxigenic strains isolated from milk and dairy products. Mol. Cell. Probes, 19: 299-305.

Dego, O.K., J.E. van Dijk and H. Nederbragt, 2002. Factors involved in the early pathogenesis of bovine Staphylococcus aureus mastitis with emphasis on bacterial adhesion and invasion-A review. Vet. Q., 24: 181-198.

Gencay, Y.E., N.D. Ayaz and A. Kasimoglu-Dogru, 2010. Enterotoxin gene profiles of Staphylococcus aureus and other Staphylococcal isolates from various foods and food ingredients. J. Fac. Vet. Med. Univ. Erciyes, 7: 75-80.

Jorgensen, H.J., T. Mork, H.R. Hogasen and L.M. Rovik, 2005. Enterotoxigenic Staphylococcus aureus in bulk milk in Norway. J. Applied Microbiol., 99: 158-166.

Juhasz-Kaszanyitsky, E., S. Janosi, P. Somogyi, A. Dan, L.van der Graaf-van Bloois, E. van Duijkeren and J.A. Wagenaar, 2007. MRSA transmission between cows and humans. Emerg. Infect. Dis., 13: 630-632.

Katsuda, K., E. Hata, H. Kobayashi, M. Kohmoto, K. Kawashima, H. Tsunemit and M. Eguchi, 2005. Molecular typing of Staphylococcus aureus isolated from bovine mastitis milk on the basis of toxin genes and coagulase gene polymorphisms. Vet. Microbiol., 105: 301-315.
Lee, J.H., 2003. Methicillin (oxacillin)- resistant Staphylococcus aureus strains isolated from major food animals and their potential transmission to humans. Applied Environ. Microbiol., 69: 6489-6494.

Moon, J.S., A.R. Lee, H.M. Kang, E.S. Lee and M.N. Kim et al., 2007. Phenotypic and genetic antibiogram of methicillin-resistant staphylococci isolated from bovine mastitis in Korea. J. Dairy Sci., 90: 1176-1185.

Normanno, G., G. La Salandra, A. Dambrosio, N.C. Quaglia and M. Corrente et al., 2007. Occurrence, characterization and antimicrobial resistance of enterotoxigenic Staphylococcus aureus isolated from meat and dairy products. Int. J. Food Microbiol., 115: 290-296.

Omoe, K., M. Ishikawa, Y. Shimoda, D.L. Hu, S. Ueda and K. Shinagawa, 2002. Detection of seg, seh and sei genes in Staphylococcus aureus isolates and determination of enterotoxin productivities of $S$. aureus isolates harboring seg, seh, or sei genes. J. Clin. Microbiol., 40: 857-862.

Ortega E., H. Abriouel, R. Lucas and A. Galvez, 2010. Multiple roles of Staphylococcus aureus enterotoxins: Pathogenicity, superantigenic activity and correlation to antibiotic resistance. Toxins, 2: 2117-2131.

Peacock, S.J., C.E. Moore, A. Justice, M. Kantzanou and L. Story et al., 2002. Virulent combinations of adhesin and toxin genes in natural populations of Staphylococcus aureus. Infect. Immun., 70: 4987-4996.

Peles, F., M. Wagner, L. Varga, I. Hei and P. Rieck et al., 2007. Characterization of Staphylococcus aureus strains isolated from bovine milk in Hungary. Int. J. Food Microbiol., 118: 186-193.

Rall, V.L.M., F.P. Vieira, R. Rall, R.L. Vieitis and A. Fernandes Jr. et al., 2008. PCR detection of staphylococcal enterotoxin genes in Staphylococcus aureus strains isolated from raw and pasteurized milk. Vet. Microbiol., 132: 408-413.

Sila, J., P. Sauer and M. Kolar, 2009. Comparison of the prevalence of genes coding for enterotoxins, exfoliatins, panton-valentine leukocidin and tsst-1 between methicillin-resistant and methicillinsusceptible isolates of Staphylococcus aureus at the university hospital in olomouc. Fac. Univ. Palacky Olomouc Czech Republic, 153: 215-218. 
Stepanovic, S., T. Hauschild, I. Dakic, Z. Al-Doori, M. Svabic-Vlahovic, L. Ranin and D. Morrison, 2006. Evaluation of phenotypic and molecular methods for detection of oxacillin resistance in members of the Staphylococcus sciuri group. J. Clin. Microbiol., 44: 934-937.

Van Loo, I., X. Huijsdens, E. Tiemersma and A. de Neeling, 2007. Emergence of methicillin-resistant Staphylococcus aureus of animal origin in humans. Emerg. Infect. Dis., 13: 1834-1839.

Velasco, D., M. del Mar Tomas, M. Cartelle, A. Beceiro and A. Perez et al., 2005. Evaluation of different methods for detecting methicillin (oxacillin) resistance in Staphylococcus aureus. J. Antimicrob. Chemother., 55: 379-382.
Wang, S.C., C.M. Wu, S.C. Xia, Y.H. Q1, L.N. Xia and J.Z. Shen, 2009. Distribution of superantigenic toxin genes in Staphylococcus aureus isolates from milk samples of bovine subclinical mastitis cases in two major diary production regions of China. Vet. Microbiol., 137: 276-281.

Zeeshan, M., K. Jabeen, E. Khan, S. Irfan, S. Ibrahim, Z. Parween and A. Zafar, 2007. Comparison of different phenotypic methods of detection of methicillin resistance in Staphylococcus aureus with the molecular detection of mec-a gene. J. Coll. Phy. Surg. Pak., 17: 666-670. 